\title{
Effect of Date of Sowing and Irrigation Regimes on Growth and Yield of Mung Bean
}

\author{
Hemadri Bag ${ }^{1 *}$, Asis Mukherjee ${ }^{2}$ and Lopamudra Bhoi ${ }^{3}$ \\ ${ }^{1}$ Bidhan Chandra Krishi Viswavidyalaya, WB, India \\ ${ }^{2}$ AICRP on Agrometeorology, Bidhan Chandra Krishi Viswavidyalaya, WB, India \\ ${ }^{3}$ Orissa University of Agriculture and Technology, ODISHA, India \\ *Corresponding author
}

\section{A B S T R A C T}

\begin{tabular}{|l|}
\hline Ke y w o r d s \\
$\begin{array}{l}\text { Biomass, Irrigation, } \\
\text { Mung bean, Yield }\end{array}$ \\
\hline Article Info \\
\hline $\begin{array}{l}\text { Accepted: } \\
\text { 15 July } 2020 \\
\text { Available Online: } \\
10 \text { August } 2020\end{array}$ \\
\hline
\end{tabular}

At "C" block farm of BCKV, Kalyani, a field experiment was conducted during the summer season of 2018, with split plot design considering two date of sowing $\left[\mathrm{D}_{1}: 7^{\text {th }}\right.$ march $2018, \mathrm{D}_{2}: 22^{\text {nd }}$ march 2018$]$ as main plot treatment and four irrigation level $\left[\mathrm{I}_{1}\right.$ : Rainfed, $\mathrm{I}_{2}$ : IW/CPE $\left.=0.50, \mathrm{I}_{3}=\mathrm{IW} / \mathrm{CPE}=0.75, \mathrm{I}_{4}=\mathrm{IW} / \mathrm{CPE}=1.00\right]$ as sub plot treatment. Result revealed that the maximum seed yield $\left(1774.9 \mathrm{~kg} \mathrm{ha}^{-1}\right)$ was recorded under early sown crop i.e. $\mathrm{D}_{1}$ which was found to be significantly higher (23\%) as compared to $\mathrm{D}_{2}\left(1354.1 \mathrm{~kg} \mathrm{ha}^{-1}\right)$. Seed yield of moong bean was significantly influenced by different irrigation schedules. Crop under rainfed condition produced maximum seed yield $\left(1724.1 \mathrm{~kg} \mathrm{ha}^{-1}\right)$ and lowest seed yield (1446.7 $\mathrm{kg} \mathrm{ha}^{-1)}$ was recorded by the treatment having no stress condition. Recorded value showed that all yield attributing character i.e. pod per plant, seed per pod, test weight $(\mathrm{g})$, total seed weight $\left(\mathrm{gm}^{-2}\right)$ were maximum in early sown crop and the crop grown under rainfed condition among all the irrigation regimes. Highest total biomass was noted under early sown crop and also under $\mathrm{I}_{1}$.

\section{Introduction}

Mung bean (Vigna radiata) is an important pulse crop after chickpea and pigeon pea. Mung bean contributes $13.86 \%$ of total area and $7.76 \%$ of total pulse production in India. The national productivity of this crop is 467 $\mathrm{kg} \mathrm{ha}{ }^{-1}$. The crop consumes less water as compared to other summer crops (Abd ElSalam et al., 2013). Mungbean roots grow deeper into the soil profile to extract water resources from greater depths (Haqqani and Pandey1994). In West Bengal Mungbean is grown mainly during summer season and contribute only $9 \%$ of country's total moong bean cultivation. Mungbean is largely grown in warm season in west Bengal; hence, the yield of Mungbean is highly dependent on adequate supply of water (Kramer and Boyer 1997). Sowing time is one of the nonmonetary inputs affecting the growth and yield of field crops under the control of the 
producer. Among the various agronomic practices, sowing time is the most important factor influencing the yield of mung bean (Ashgar et al., 2006). Reduced water availability during pre monsoon summer period restricts the growth of summer mung bean (Kumar et al., 1992). As mung bean is a less water requiring crop, the present investigation was carried out to assess the effect of sowing date and irrigation regimes on yield, evapotranspiration and water use efficiency and to screen out optimum date of sowing and irrigation frequency for mung bean cultivation in New Alluvial Zone of West Bengal.

\section{Materials and Methods}

\section{Experimental site}

Field experiment was carried out during the pre Kharif season (March-June) 2018 in CBlock Farm of Bidhan Chandra Krishi Viswavidyalaya, Kalyani, (Latitude 22 059'13''N, Longitude 88 027'20''E and altitude of $10.8 \mathrm{~m}$ AMSL ) West Bengal, India. The agro climatic sub zone of this region is hot and sub-humid. Normal annual rainfall is $1600 \mathrm{~mm}$ and $85 \%$ of it is received during monsoon period (June-Sept). May is the hottest period with average temperature of $27.6{ }^{\circ} \mathrm{C}$ to $31.10 \mathrm{C}$ and January is the coldest month $\left(15.5^{0} \mathrm{C}\right.$ to $\left.21.3^{\circ} \mathrm{C}\right)$. The soil of the experimental site is Entisol with sandy loam texture.

\section{Experimental design and treatments}

The experiment was carried out in split plot design with two date of sowing (DOS, $\mathrm{D}_{1}$ : 07.03.2018, $\mathrm{D}_{2}$ : 22.03.2018) as main plot treatment and four irrigation management $\left(\mathrm{I}_{1}\right.$ : Rainfed, $\mathrm{I}_{2}: \mathrm{IW} / \mathrm{CPE}=0.50, \mathrm{I}_{3}: \mathrm{IW} / \mathrm{CPE}=0.75$ and $\mathrm{I}_{4}: \mathrm{IW} / \mathrm{CPE}=1.00$ ) as sub plot treatment. Individual plot size was $5 \mathrm{~m} \times 3.5 \mathrm{~m}$ with spacing of $30 \mathrm{~cm}(\mathrm{R} \times \mathrm{R})$ and $10 \mathrm{~cm}(\mathrm{P} \times \mathrm{P})$.
Synthetic fertilizer was applied during land preparation@ $20 \mathrm{~kg} \mathrm{~N} / \mathrm{ha}, 40 \mathrm{~kg} \mathrm{P} / \mathrm{ha}$ and 20 $\mathrm{kg} \mathrm{K} / \mathrm{ha}$ through urea, SSP and MOP respectively as basal dose.

\section{Sowing}

The crop was sown on $7^{\text {th }}$ March 2018 and $22^{\text {nd }}$ March 2018. Line sowing with $3 \mathrm{~cm}$ depth was done with row to row spacing of 30 $\mathrm{cm}$ and plant to plant spacing of $20 \mathrm{~cm}$.

\section{Irrigation}

A pre-sowing irrigation of $30 \mathrm{~mm}$ was given before sowing. The post sowing irrigations were applied as per treatments by calculating $\mathrm{CPE}$ value, if any rainfall occurred during that period than that amount of rainfall was deducted from the depth of irrigation and rest amount of water was given through irrigation to maintain IW/CPE ratio.

\section{Harvesting}

The crop was harvested at physiological maturity stage. The grain yield was recorded after proper sun drying and threshing of the crop.

\section{Observation}

The following yield and yield attributes were determined in each sub plot; no. of pods per plant at harvesting, seed per pod, Test weight (g), Total seed weight $\left(\mathrm{g} \mathrm{m}^{-2}\right)$ and Straw yield $\left(\mathrm{kg} \mathrm{ha}^{-1}\right)$, Chaff yield $\left(\mathrm{kg} \mathrm{ha}^{-1}\right)$, Grain yield(kg $\mathrm{ha}^{-1}$ ). Recorded biometric observation includes plant height and total biomass.

\section{Statistical analysis}

Statistical analysis was done by using the standard procedure of split plot design (Gomez and Gomez, 1984) to draw a valid conclusion. 


\section{Results and Discussion}

\section{Plant height}

Plant height is one of the most important growth parameters of any crop. It is an index of growth and development, representing the infrastructure build-up by the plant over a period of time. The variation of plant height between two dates of sowing was significant during all the growth stage. The data revealed plant height increased progressively with the advancement of crop growth stages from initial to harvest. During harvesting the highest plant height $(54.55 \mathrm{~cm})$ was recorded under $\mathrm{D}_{1}$ which was $3.8 \%$ more than $\mathrm{D}_{2}$.

The highest plant height under $\mathrm{D}_{1}$ might be due to favorable soil moisture and temperature for growth during early sowing. Though there was no significant variation among irrigation treatments the highest plant height $(53.97 \mathrm{~cm})$ was recorded under $I_{1}$ and lowest plant height $(53.23 \mathrm{~cm})$ recorded under $\mathrm{I}_{3}$ at harvest. Non significant variation might be due to soil moisture condition which was attained by rainfall during the crop growing period. Interaction effects were found nonsignificant at all crop growth stages (Table 1). Kaur (2014), Kumar and Kumawat (2014), Patel (2014), Puste et al., (2014), Idnani and Singh (2008), Laekemariam (2013) and Rehman et al., (2004) observed the same.

\section{Total biomass}

Irrespective of irrigation regimes, the variation of total biomass during different crop growth stage was increased significantly up to early pod formation stage (S3), afterward it showed non-significant variation till harvest (S5). With the advancement of crop growing stage the total biomass was progressively increased under both sowing date. At harvest (S5) the maximum total biomass was recorded $35.60 \mathrm{~g} \mathrm{plant}^{-1}$ and
29.25 g plant $^{-1}$ under $D_{1}$ and $D_{2}$ respectively The total biomass under $\mathrm{D}_{1}$ was higher than $\mathrm{D}_{2}$ during crop growing period (Fig. 1). Irrespective of date of sowing, the variation of total biomass among irrigation treatments, during different crop growth stage was statistically insignificant. At harvest (S5) the maximum (33.91 $\mathrm{g} \mathrm{plant}^{-1}$ ) total biomass was recorded under $I_{1}$ and the minimum $(30.04 \mathrm{~g}$ plant $^{-1}$ ) total biomass was recorded under $\mathrm{I}_{4}$. Higher soil moisture under $\mathrm{I}_{4}$ might have negative impact on total biomass accumulation (Fig. 2).

\section{Yield and yield attributes at harvest}

\section{Pod per plant}

The number of pods per plant is an important yield determining component of crop growth. More pods per plant are associated with higher yield potentiality. Experimental study reveals significant differences in number of pods per plant under different dates of sowing. The maximum number of pods per plant (59.3) was observed under $\mathrm{D}_{1}$ sowing date which was significantly superior over $\mathrm{D}_{2}$ (45.6). Though there was non-significant variation was observed under different irrigation treatment, the maximum pod per plant (62) recorded under $I_{1}$ and minimum pod per plant (43.7) was recorded under $\mathrm{I}_{4}$. Kaur (2014), Chovatia et al., (1993), Sekhon and Singh (2005), Singh and Singh (2009), Palsaniya et al., (2013), also recorded the same.

\section{Seed per pod}

Number of seeds per pod is considered an important parameter as it deals with the potential yield recovery in leguminous crops. Data on number of seeds per pod under different dates of sowing and irrigation schedules is being given in Table 2. The data on number of seeds per pod indicated no 
significant differences due to different dates of sowing and subsequent irrigation schedules. The highest number of seeds per pod (11.9) was observed in $\mathrm{D}_{2}\left(22^{\text {nd }}\right.$ March) sowing date as compared to $\mathrm{D}_{1}\left(7^{\text {th }}\right.$ march) sowing date (11.6). Sekhon and Singh (2005) also observed no significant differences in number of seeds per pod under different dates of sowing. Monem et al., (2012), Kaur (2014), Palsaniya et al., (2013), Singh and Singh (2009), Chovatia et al., (1993), and Raza et al., (2012) recorded the same.

There was no significant variation was observed under different irrigation treatment, however the maximum seed per pod (11.8) was recorded under $I_{1}, I_{3}$ and $I_{4}$ and the minimum seed per pod (11.7) was recorded under $\mathrm{I}_{2}$.

\section{Test weight}

The test weight is an important index which indicates the efficiency of the seed filling process and governs the seed yield of moong. It reflects the nature and extent of seed development and is a function of various production factors that influences seed development and filling patterns.

The data regarding test weight as affected by sowing dates and irrigation scheduling is presented in Table 2. The data revealed nonsignificant difference due to different dates of sowing. The highest (292.2 g) teat weight was observed under $\mathrm{D}_{1}$ sowing date, which was $28.8 \mathrm{~g}$ higher than $\mathrm{D}_{2}$ sowing dates. However, thousand-seed weight was non significantly influenced by irrigation schedules. The highest test weight (319.4 g) was recorded with irrigation schedule of $\mathrm{I}_{2}$ and lowest seed weight $(247.7 \mathrm{~g})$ was recorded under $\mathrm{I}_{3}$ which was 22\% higher. Monem et al., (2012), Kaur (2014), Palsaniya et al., (2013) and Sekhon and Singh (2005) also found the same results.

\section{Total seed weight per $\mathbf{m}^{2}$}

Recorded data reveals significant difference due to different dates of sowing. The highest $(177.5 \mathrm{~g})$ 1000-seed weight was observed under $\mathrm{D}_{1}$ sowing date, which was $42.1 \mathrm{~g}$ higher than $D_{2}$ sowing dates. However, thousand-seed weight was significantly influenced by irrigation schedules. The highest 1000 -seed weight (172.4 g) was recorded with irrigation schedule of $\mathrm{I}_{1}$ and lowest seed weight $(144.7 \mathrm{~g})$ was recorded under $\mathrm{I}_{4}$ which was $16 \%$ higher.

\section{Straw yield}

Straw yield is an index of the vegetative growth of the crop. The data on straw yield are important tool for making the assessment of the effect of different irrigation treatments on the vegetative growth of the plant. The data on the straw yield of summer moong is presented in Table 2. The maximum straw yield $\left(3174.2 \mathrm{~kg} \mathrm{ha}^{-1}\right)$ was recorded under late sown crop i.e. $\mathrm{D}_{2}\left(22^{\text {nd }}\right.$ March $)$ which was found to be significantly better as compared to $\mathrm{D}_{1}\left(7^{\text {th }}\right.$ March) sowing dates. Higher straw yield in case of $D_{2}$ sowing date might be due to higher dry matter accumulation and total biomass of crop plant (Table 2). Straw yield of moong was significantly influenced by different irrigation schedules. Irrigation scheduled of $\mathrm{I}_{1}$ treatment produced maximum straw yield (3146.7 $\left.\mathrm{kg} \mathrm{ha}^{-1}\right)$ which was statistically at par with $I_{3}$ and $I_{4}$ irrigation schedules.

The reason for increased straw yield under $I_{1}$ might be due to more efficient photosynthesis as the optimum required amount of water demands were fulfilled better by rainfall and the plants produced more dry matter and leaf area and ultimately higher straw yield. Kaur (2014) and Kumar et al., (2009) recorded the same. 


\section{Stover yield}

Stover yield is an index of the vegetative growth of the crop. The data on the stover yield of summer moong are given in Table 2 . The maximum stover yield $\left(843.7 \mathrm{~kg} \mathrm{ha}^{-1}\right)$ had been reported under early sown crop i.e. $\mathrm{D}_{1}\left(27^{\text {th }}\right.$ March $)$ which was found to be significantly higher as compared to $\mathrm{D}_{2}\left(22^{\text {nd }}\right.$ March) sowing date. Stover yield of moong was significantly influenced by different irrigation schedules. Irrigation scheduled of $\mathrm{I}_{1}$ produced maximum stover yield (927.6 $\left.\mathrm{kg} \mathrm{ha}^{-1}\right)$ and lowest stover yield $(768.8 \mathrm{~kg}$ $\mathrm{ha}^{-1}$ ) was recorded under $\mathrm{I}_{4}$.

\section{Seed yield}

Seed yield is the most important criterion for evaluating and comparing the efficiency of experimental variables because seed yield is a function of diverse characters like number of pods per plant, seeds per pod and 1000-seed weight. The data regarding moong seed yield as affected by sowing dates and irrigation scheduling is presented in Table 2 . The maximum seed yield $\left(1774.9 \mathrm{~kg} \mathrm{ha}^{-1}\right)$ was recorded under early sown crop i.e. $\mathrm{D}_{1}$ which was found to be significantly better as compared to $\mathrm{D}_{2}\left(1354.1 \mathrm{~kg} \mathrm{ha}^{-1}\right)$ sowing dates which was recorded $23 \%$ more. Seed yield of moong bean was also significantly influenced by different irrigation schedules. Irrigation scheduled of $\mathrm{I}_{1}$ produced maximum seed yield $\left(1724.1 \mathrm{~kg} \mathrm{ha}^{-1}\right)$ and lowest seed yield (1446.7 $\mathrm{kg} \mathrm{ha}^{-1}$ ) which was statistically at par with $\mathrm{I}_{3}$ $\left(1558.6 \mathrm{~kg} \mathrm{ha}^{-1}\right)$ and $\mathrm{I}_{2}\left(1528.6 \mathrm{~kg} \mathrm{ha}^{-1}\right)$ irrigation schedules. Monem et al., (2012), Palsaniya et al., (2013), Kumar and Kumawat (2014), Chovatia et al., (1993), Bhingharde and Dumbre (1994), Kumar et al., (2009), Ram and Dixit (2001), Sarkar et al., (2004), Singh and Vashist (2005), Tijare et al., (2017) and Singh and Singh (2009), Raza et al., (2012) also found the same result.

Table.1 Effect of date of sowing and irrigation regimes on plant height $(\mathrm{cm})$ of green gram

\begin{tabular}{|c|c|}
\hline Treatments & Plant height \\
\hline Date of sowing (DOS) & \\
\hline $\mathbf{D}_{\mathbf{1}}$ & 54.55 \\
\hline $\mathbf{D}_{\mathbf{2}}$ & 52.55 \\
\hline SEm $(\mathbf{\pm})$ & 0.12 \\
\hline $\mathbf{C D}(\mathbf{P}=\mathbf{0 . 0 5})$ & 0.71 \\
\hline Irrigation $(\mathbf{I})$ & \\
\hline $\mathbf{I}_{\mathbf{1}}$ & 53.97 \\
\hline $\mathbf{I}_{\mathbf{2}}$ & 53.27 \\
\hline $\mathbf{I}_{\mathbf{3}}$ & 53.23 \\
\hline $\mathbf{I}_{\mathbf{4}}$ & 53.73 \\
\hline $\mathbf{S E m}(\mathbf{\pm})$ & 0.24 \\
\hline $\mathbf{C D}(\mathbf{P}=\mathbf{0 . 0 5})$ & $\mathrm{NS}$ \\
\hline
\end{tabular}


Table. 2 Effect of date of sowing and irrigation regimes on yield attributes at harvest

\begin{tabular}{|c|c|c|c|c|c|c|c|}
\hline Treatments & $\begin{array}{c}\text { Pod per } \\
\text { plant }\end{array}$ & $\begin{array}{l}\text { Seed per } \\
\text { pod }\end{array}$ & $\begin{array}{c}\text { Test } \\
\text { weight }(g)\end{array}$ & $\begin{array}{c}\text { Total seed } \\
\text { weight } \\
\left(\mathrm{g} \mathrm{m}^{-2}\right)\end{array}$ & $\begin{array}{c}\text { Straw } \\
\text { yield } \\
\left(\mathrm{kg} \mathrm{ha}^{-1}\right)\end{array}$ & $\begin{array}{c}\text { Stover } \\
\text { yield } \\
\left(\mathrm{kg} \mathrm{ha}^{-1}\right)\end{array}$ & $\begin{array}{c}\text { Seed } \\
\text { yield } \\
\left(\mathrm{kg} \mathrm{ha}^{-1}\right)\end{array}$ \\
\hline \multicolumn{8}{|l|}{$\begin{array}{c}\text { Date of } \\
\text { sowing (DOS) }\end{array}$} \\
\hline$D_{1}$ & 59.3 & 11.6 & 292.2 & 177.5 & 2617.5 & 843.7 & 1774.9 \\
\hline $\mathbf{D}_{2}$ & 45.6 & 11.9 & 263.4 & 135.4 & 3174.2 & 805.2 & 1354.1 \\
\hline $\operatorname{SEm}( \pm)$ & 1.9 & 0.1 & 15.7 & 0.2 & 78.9 & 6.1 & 2.1 \\
\hline $\mathrm{CD}(P=0.05)$ & 11.5 & NS & NS & 1.3 & 479.9 & 37.1 & 12.7 \\
\hline \multicolumn{8}{|l|}{ Irrigation (I) } \\
\hline$I_{1}$ & 62.00 & 11.80 & 253.50 & 172.40 & 3146.70 & 927.60 & 1724.10 \\
\hline $\mathbf{I}_{2}$ & 47.30 & 11.70 & 319.40 & 152.90 & 2458.30 & 796.30 & 1528.60 \\
\hline $\mathbf{I}_{3}$ & 56.80 & 11.80 & 247.70 & 155.90 & 3071.70 & 805.30 & 1558.60 \\
\hline $\mathbf{I}_{4}$ & 43.70 & 11.80 & 290.70 & 144.70 & 2906.70 & 768.80 & 1446.70 \\
\hline $\operatorname{SEm}( \pm)$ & 6.2 & 0.1 & 35.2 & 5.8 & 163.8 & 32.9 & 58.1 \\
\hline $\mathrm{CD}(\mathrm{P}=0.05)$ & NS & NS & NS & 17.9 & 504.9 & 101.4 & 179.1 \\
\hline
\end{tabular}

Fig.1 Variation of total biomass during various crop growth stages

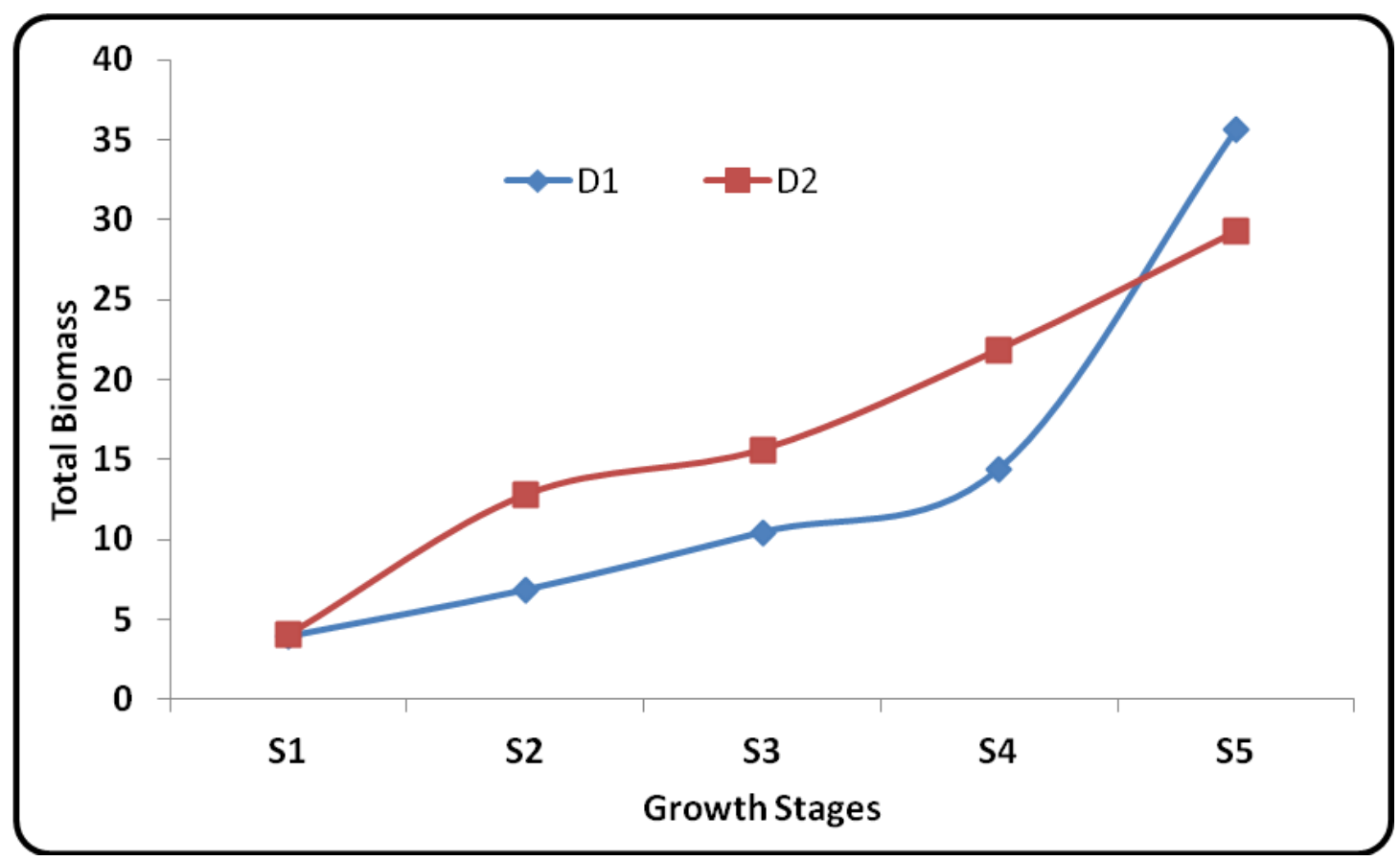

[S1;Branching,S2 ;Flowering,S3 ; Early pod formation,S4 ; Early pod maturity,S5 ;Harvest] 
Fig.2 Variation of Total biomass during various crop growth stages

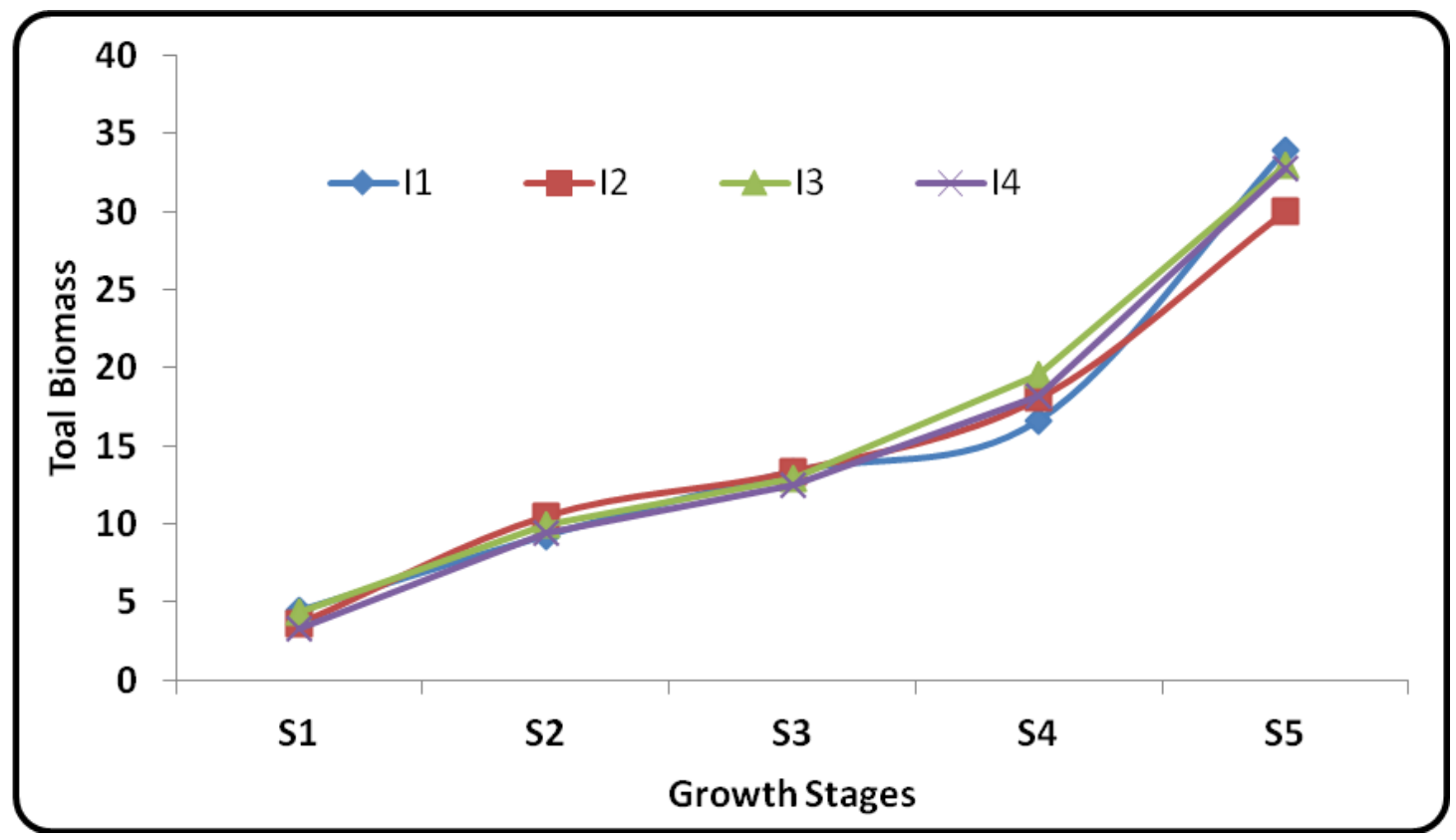

[S1;Branching,S2 ;Flowering,S3 ; Early pod formation,S4 ; Early pod maturity,S5 ;Harvest]

It is concluded that mung bean crop sown during $1^{\text {st }}$ week of March produced higher pod per plant and 1000 seed weight which subsequently resulted highest seed yield. Delay in sowing date by 15 days resulted $31 \%$ yield reduction. Thus, early sowing is recommended for growing mung bean in new alluvial agro climatic zone. In this study highest seed yield was recorded under rainfed $\left(\mathrm{I}_{1}\right)$ condition, which was $16 \%$ lower under $100 \%$ irrigation treatment. As mung bean is a low water requiring crop, $100-150 \mathrm{~mm}$ available water is sufficient for achieving higher yield.

\section{Acknowledgement}

The author duly acknowledges the support received from AICRP on Agrometeorology, Directorate of research, BCKV.

\section{References}

AbdEl-Salam MS, El-Metwally IM, Abd ElGhany HM, Hozayn M. (2013).
Potentiality of using mungbean as a summer legume forage crop under Egyptian condition. Journal of Applied Sciences Research. 9: 1238-1243

Ashgar M, Saleem M M F, Ali A and Ishaq R A F (2006) Effect of sowing dates and planting patterns on growth and yield of mungbean. J Agric Res 44:139-46.

Bhingarde M T and Dumbre A D (1994). Effect of sowing dates and seed size on seed yield and quality of mungbean under summer conditions. J Mha Agric Univ 19: 410-17.

Chovatia P K, Ahlawat R P S and Trivedi S J (1993). Growth and yield of summer greengram (Phaseolus radiatus) as affected by different dates of sowing, Rhizobium inoculation and levels of phosphorous. Indian J Agron 38: 492-94. Haqqani AM and Pandey RK. (1994). Response of Mungbean to aterstress and irrigation at various growth stages and plant densities: II. Yield and yield components. Tropical Agriculture 71 (4): 289-294

Idnani L K and Singh R (2008). Effect of 
irrigation regimes, planting and irrigation methods and arbuscular mycorrhizae on productivity, nutrient uptake and water use in summer greengram (Vigna radiata var radiata). Indian J Agric Sci 78: 53-57.

Kaur Navneet (2014). Growth, yield, and water productivity of bed planted summer moong in relation to irrigation regimes. Punjab Agricultural University, Ludhiana.

Kumar R and Kumawat N (2014). Effect of sowing dates, seed rates and integrated nutrition on productivity, profitability and nutrient uptake of summer mungbean in Eastern Himalaya. Arch Agron Soil Sci 60: 1207-27.

Laekemariam Fanuel and Worku Walelign (2013). Growth, light interception, radiation use efficiency and productivity of mungbean as influenced by sowing date. Ethiop. J. Biol. Sci. 12(2): 117-133.

Monem Reza, Mirtaheri Seied Mehdi and Ahmadi Ali (2012). Investigation of row orientation and planting date on yield and yield components of Mung bean. Annals of Biological Research, 2012, 3 (4):1764-1767.

Palsaniya Shersingh, Puniya R, Sharma Ashu, Bazaya B R, Kachroo Dileep (2013). Effect of sowing dates and varieties on growth, yield and nutrient uptake of summer mungbean (Vigna radiata). Indian Society of Agronomy, vol.61 (2).

Puste A.M, Mandal T.K, Gunri S.K, Devi T.K and Pramanik B.R (2014). Growth, yield and advantage of green gram-sesame intercropping under different irrigation regimes in new alluvial zone of West
Bengal. Journal of crop and weed 10(1):19-24.

Ram S N and Dixit R S (2000) Effect of dates of sowing and phosphorous on nodulation, uptake of nutrients amd yield of summer greengram [Vigna radiata (L.) wilczek]. Crop Res 19: 414-17.

Raza M.H, Sadozai G.U, Baloch M.S, Khan E.A, Din I and Wasim K (2012). Effect of Irrigation Levels on Growth and Yield of Mungbean. Pakistan Journal of Nutrition 11 (10): 974-977, ISSN 16805194.

Rehman Abdur, Khan Khalil Shad, Nigar Shaheen, Rehman Sadur, Haq Ikramul, Akhtar Sohail, Khan Amir Zaman and Shah Syed Rehmat (2009). Phenology, plant height and yield of Mung bean variety in response to planting date. Sarhad J. Agric. Vol.25, No.2.

Sarkar A R, Kabir H, Begum M and Salam A (2004). Yield performance of mungbean as affected by planting dates, variety and plant density. J Agron 3: 18-24.

Sekhon H S and Singh Guriqbal (2005). Influence of date of sowing and seed rate on the growth and yield of summer mungbean (Vigna radiata (L.) wilczek). Indian J Ecol 32: 157-60.

Singh H and Vashist K (2005) Sowing time of summer mungbean under Punjab conditions. Indian J Pulses Res 18: 3637.

Tijare Bharti, Chorey Anita, Bhale Vilas and Kakde Sanjay (2017). Phenology and Heat Unit Requirement of Summer Green Gram Varieties under Different Sowing Windows. Int.J.Curr.Microbiol. App.Sci 6(4): 685-691.

\section{How to cite this article:}

Hemadri Bag, Asis Mukherjee and Lopamudra Bhoi. 2020. Effect of Date of Sowing and Irrigation Regimes on Growth and Yield of Mung Bean. Int.J.Curr.Microbiol.App.Sci. 9(08): 1274-1281. doi: https://doi.org/10.20546/ijcmas.2020.908.144 